\title{
Effects of fermentation and drying durations on the quality of cocoa (Theobroma cacao L.) beans during the rainy season in the Juaboso District of the Western-North Region, Ghana
}

\author{
Emmanuel Ackah ${ }^{*^{*}}$ and Eric Dompey ${ }^{2}$
}

\begin{abstract}
Background: Postharvest treatments are crucial to the quality of cocoa finished products. This study aimed at investigating the effects of durations of fermentation and drying on the quality of cocoa (Theobroma cacao) beans during the rainy season. The study employed a $4 \times 3$ factorial with four fermentation durations of 5, 6, 7 and 8 days and three drying periods of 4, 5 and 6 days, resulting in a total of 12 treatment combinations, laid in a Completely Randomized Design with three replications. Bean quality data were collected on bean count/100 g, moisture content and cut test attributes including mouldy, slaty and purple, as well as percentage purity.

Results: The study showed that the applied fermentation and drying periods single handedly resulted in moisture content higher than the recommended, coupling 8 days fermentation with 6 days drying period resulted in a moisture content of 5.6\% which falls below the acceptable standard (7.5\%) recommended. Number of beans/100 g increased with increasing fermentation and drying periods. Coupling any of the fermentation periods with 5 or 6 days drying duration resulted in mould content within the acceptable grade 1 limit (3\%). Longer fermentation period coupled with any of the drying durations resulted in very encouraging and minimal values of purple, while coupling 6,7 or 8 days fermentation period with 6 days drying resulted in slaty content within the grade 1 limit (3\%).

Conclusion: The overall effect of the treatments on the quality attributes from the cut test revealed that 8 days fermentation with the traditional leave heap method, coupled with 6 days sun drying during the rainy season, resulted in superior bean quality with a percentage purity of $98.00 \%$.
\end{abstract}

Keywords: Cocoa, Bean quality, Fermentation, Drying, Theobroma cacao

\section{Background}

Cocoa (Theobroma cacao) is one of the ancient crops of the lowland tropical forest believed to have originated from Central and Southern America (Presilla 2009; Coe and Coe 2013). Presently, 50 countries cultivate the crop on $0.2 \%$ of the world's agricultural land. Cocoa has now

\footnotetext{
*Correspondence: bigemma1995@gmail.com

1 Department of Crop and Soil Science, College of Agriculture Education, University of Education, Winneba, Ashanti-Mampong, Ghana

Full list of author information is available at the end of the article
}

become one of the most important agricultural export commodities in the world (FAO 2003). Based on quantity produced, the top five producers are Côte d'Ivoire (36\%), Ghana (22\%), Indonesia (11\%), Nigeria (6\%), and Brazil (5\%) (ICCO 2013).

Cocoa is believed to have been introduced into Ghana by Tetteh Quarshie in 1879 from Fernando Po. However, there is the existence of some evidence in the record of the Basel Mission in Accra indicating that cocoa was already growing in their compound long before that time (Afoakwa 2010; Danker 2002). About 8,000,000 farming families in six regions cultivate cocoa on about 1.5 
million hectares of Ghanaian agricultural land (Afoakwa 2010). Cocoa is now the backbone supporting the economies of some West African countries including Ghana. The country is almost synonymously known by the crop, with the slogan "Ghana, Cocoa! Cocoa, Ghana"! This as a result of the crucial role played by the crop in the nation's economy (Anyidoho 2015). Cocoa averagely contributes 6\% of Ghana's Gross Domestic Product (GDP) (ICCO 2007).

Cocoa beans are usually processed into chocolate, cocoa powder, cocoa liquor, cocoa butter and cake (Anyidoho 2015). Essentially, cocoa powder is used in flavouring biscuits, ice cream, dairy products, drinks and cakes and in the manufacture of coatings for confections and frozen desserts (Rossini et al. 2011). Cocoa is also used as a raw material in the cosmetics and pharmaceutical industries (Anyidoho 2015). Presently, the pod husks and shells are used in formulating animal feed and fertilizer in Ghana (Ntiamoah and Afrane 2008). The dried pods are also grounded and used in soap preparation.

Postharvest treatments are very important to the quality of cocoa finished products as they initiate the formation of chocolate flavour precursors and affects the brown colouration of cocoa products (Adeyeye et al. 2010). In Ghana, postharvest operations are done manually and excellently by small-scale farmers, leading to superior quality specifications. This is the major reason why the Ghanaian cocoa has received a worldwide reputation as the ingredient of preference by quality-oriented cocoa products manufacturers (Jonfia-Essien 2001). The cocoa industry has continually advocated the maintenance of quality and further improvement in the preparation of exported cocoa beans and processing into finished products by minimizing the current levels of defective beans. Assessment of postharvest activities which may be potential contributing factors to enable policymakers and extension services to prepare appropriate methodologies to address such quality challenges is a continual activity in Ghana (Otomfo 2014).

The processing chain of cocoa beans consists of two critical steps, namely fermentation and drying. Fermentation and drying are both essential steps affecting the quality of the final product (Guehi et al. 2010). These steps are the major determinants of the acceptability or rejection of beans on the international market (Yao et al. 2017). Poor fermentation of cocoa beans leads to poor-quality chocolate (Schwan and Wheals 2004). Poor fermentation as a postharvest defect depicted by the presence of purple, slaty and germinated beans in marketed cocoa has adversely affected the cocoa industry (Quality Control Company [QCC] 2010). After fermentation, cocoa beans are dried to reduce the moisture content from about $60 \%$ to between 6 and 8\% (Nair 2010).
Under high moisture (above 8\%), there is the danger of internal mould growth, while below 5\% moisture, the beans are very brittle (Thompson et al. 2001). Drying fermented cocoa beans also allow the continuation of some chemical changes which occur during fermentation to improve flavour development. This goes on either until the moisture content drops to below $7 \%$ or until enzymatic activities ceases (Kyi et al. 2005). Drying influences market quality, the development of flavour, final bean acidity, mouldiness and the presence of off-flavour such as smoky notes in the beans (Afoakwa et al. 2015).

During rainy or wet conditions, a drying duration of about 22 days may be needed, and during the dry season, sun drying may last for 7 days or less (Lasisi 2014). Climatic conditions in the tropics, characterized by high humidity levels of 70 to $90 \%$ r.h. and temperatures around $30{ }^{\circ} \mathrm{C}$, make it ideal for the development of storage insects and moulds on cocoa beans (Navarro et al. 2010). Moreover, growers, as well as "caretakers", may think that providing 'wet' cocoa is in their favour: that not only is the cocoa available sooner (and paid for earlier), but that if the cocoa contains high moisture (i.e. is not properly dried), it weighs more and so will attract a higher return (International Trade Centre UNCTAD/ WTO 2001). Although several studies (Afoakwa et al. 2015; Dharmaputra 1999; Lefeber et al. 2010; Adeniyi et al. 2011; Kouadio et al. 2015; Otomfo 2014) have indicated the effects of fermentation and drying on the quality of cocoa beans, no focus has been directed to how the duration of these factors interactively affects cocoa bean quality. And the fact that no or little concern has been raised on the production of quality cocoa using the traditional fermentation and drying durations in the study area calls for intensive research work to address the issue. This study, therefore, aimed at investigating the effects of four durations of fermentation and three drying periods on the quality of cocoa beans in the Juaboso district and its environs.

\section{Methods \\ The study area}

The study was conducted at Sefwi-Asempaneye in the Juaboso District of the Western (North) Region of Ghana. The district shares borders with Bia and Asunafo North Municipal to the north, Asunafo South and SefwiWiawso district to the east, Bodi district to the south and La Cote d"Ivoire to the west. The area is located $360 \mathrm{~km}$ to the north-west of the Sekondi-Takoradi Metropolis, the then Regional Capital. The district forms part of the country's dissected plateau with isolated hills ranging between 300 and $390 \mathrm{~m}$ above sea level (Ghana Statistical Service 2014). The district lies in the wet semi-equatorial climatic zone with two rainfall peaks (maxima) in 


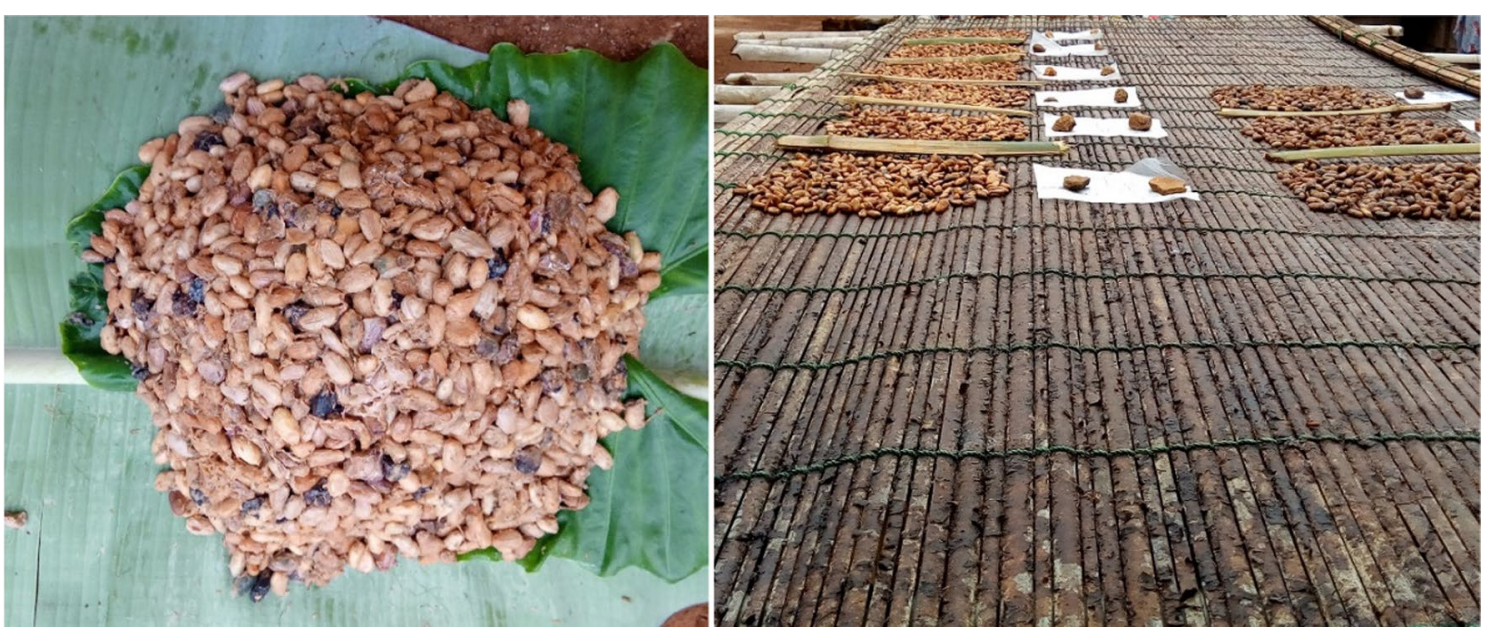

Fig. 1 Fermentation and Drying of sampled cocoa beans with traditional leaf heap method and sun drying

May-June and September-October. The mean annual temperature for the district ranges between 25 and $26^{\circ} \mathrm{C}$. The area experiences two main wet and dry seasons. The wet season is between April and October, and the dry season is between November and March. The relatively long wet (rainy) season favours the cultivation of many food and cash crops, especially cocoa. The Krokosue forest, which is earmarked as a forest reserve, enhances the district's ecosystem (Ghana Statistical Service 2014).

\section{Experimental design and treatments}

The experiment was carried out as a $4 \times 3$ factorial laid in a Completely Randomized Design (CRD). The factors included fermentation and drying periods, with four fermentation treatments of 5, 6, 7 and 8 days and three drying treatments of 4, 5 and 6 days.

This resulted in 12 treatment combinations including:

\begin{tabular}{|c|c|c|c|}
\hline T1: & $\begin{array}{l}5 \text { days fermentation }+4 \text { days } \\
\text { drying }\end{array}$ & T7: & $\begin{array}{l}7 \text { days fermentation }+4 \text { days } \\
\text { drying }\end{array}$ \\
\hline T2: & $\begin{array}{l}5 \text { days fermentation }+5 \text { days } \\
\text { drying }\end{array}$ & T8: & $\begin{array}{l}7 \text { days fermentation }+5 \text { days } \\
\text { drying }\end{array}$ \\
\hline & $\begin{array}{l}5 \text { days fermentation }+6 \text { days } \\
\text { drying }\end{array}$ & T9: & $\begin{array}{l}7 \text { days fermentation }+6 \text { days } \\
\text { drying }\end{array}$ \\
\hline & $\begin{array}{l}6 \text { days fermentation }+4 \text { days } \\
\text { drying }\end{array}$ & T10: & $\begin{array}{l}8 \text { days fermentation }+4 \text { days } \\
\text { drying }\end{array}$ \\
\hline & $\begin{array}{l}6 \text { days fermentation }+5 \text { days } \\
\text { drying }\end{array}$ & T11: & $\begin{array}{l}8 \text { days fermentation }+5 \text { days } \\
\text { drying }\end{array}$ \\
\hline & $\begin{array}{l}6 \text { days fermentation }+6 \text { days } \\
\text { drying }\end{array}$ & T12: & $\begin{array}{l}8 \text { days fermentation }+6 \text { days } \\
\text { drying }\end{array}$ \\
\hline
\end{tabular}

\section{Harvesting and resting of cocoa pods}

Fully ripe cocoa fruits were collected from fruits of Hybrid C 70 clonal type developed by the Cocoa Research
Institute of Ghana (CRIG) in 1984 and had been planted in 1997 (16-year-old cocoa trees) in a cocoa farm at Sefwi-Asempaneye. A total of 300 cocoa pods were randomly harvested during the 2018/2019 main crop season. Debris and blemished pods were removed from the harvested stock and allowed to rest for 3 days, consistent with farmer practise according to personal enquiry from some farmers.

\section{Pod breaking}

Beans were extracted from rested pods by breaking with a blunt-edged cutlass to facilitate bean-scooping from pods.

\section{Fermentation and drying}

The traditional heap fermentation method was used in fermenting the fresh beans by covering with fresh banana leaves (Fig. 1). A total of $6 \mathrm{~kg}$ fresh beans was divided into four samples of $1.5 \mathrm{~kg}$ each for the four fermentation periods of 5, 6, 7 and 8 days. At the end of each fermentation period, the sample was again divided into three for the three drying periods of 4, 5 and 6 days. All the fermented samples were dried on a mat made of raffia palm fronds with a dimension of $2 \mathrm{~m} \times 2.5 \mathrm{~m}$ and raised to about $1 \mathrm{~m}$ high on wooden and bamboo frame as shown in Fig. 1. Drying was done in July 2019, where rainfall was frequent, coupled with high relative humidity and low temperature.

\section{Bean storage}

The fermented and dried beans were stored for 30 days (1 month) to determine which fermentation and drying period will result in the development of defects in the 


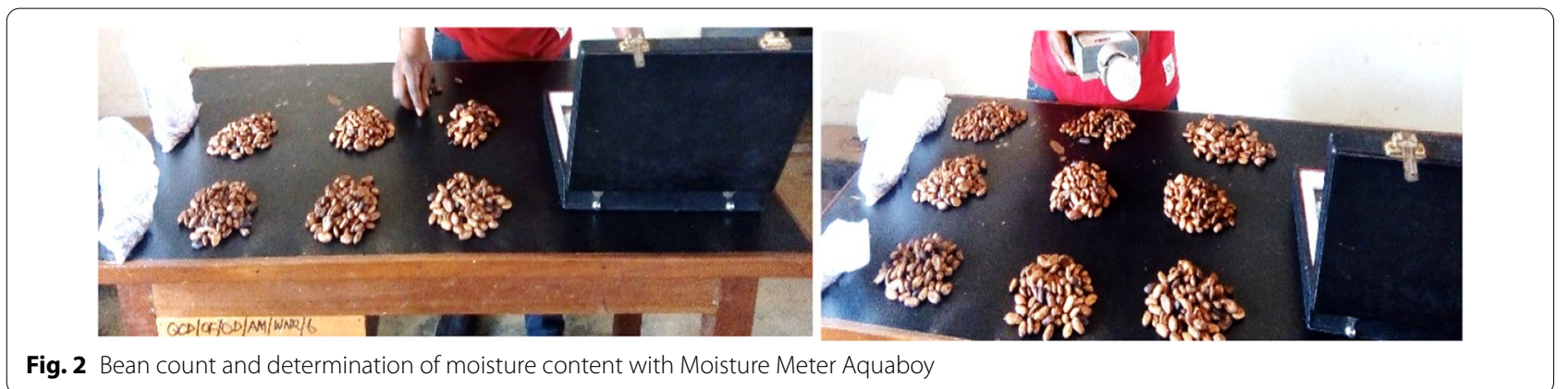

Fig. 2 Bean count and determination of moisture content with Moisture Meter Aquaboy

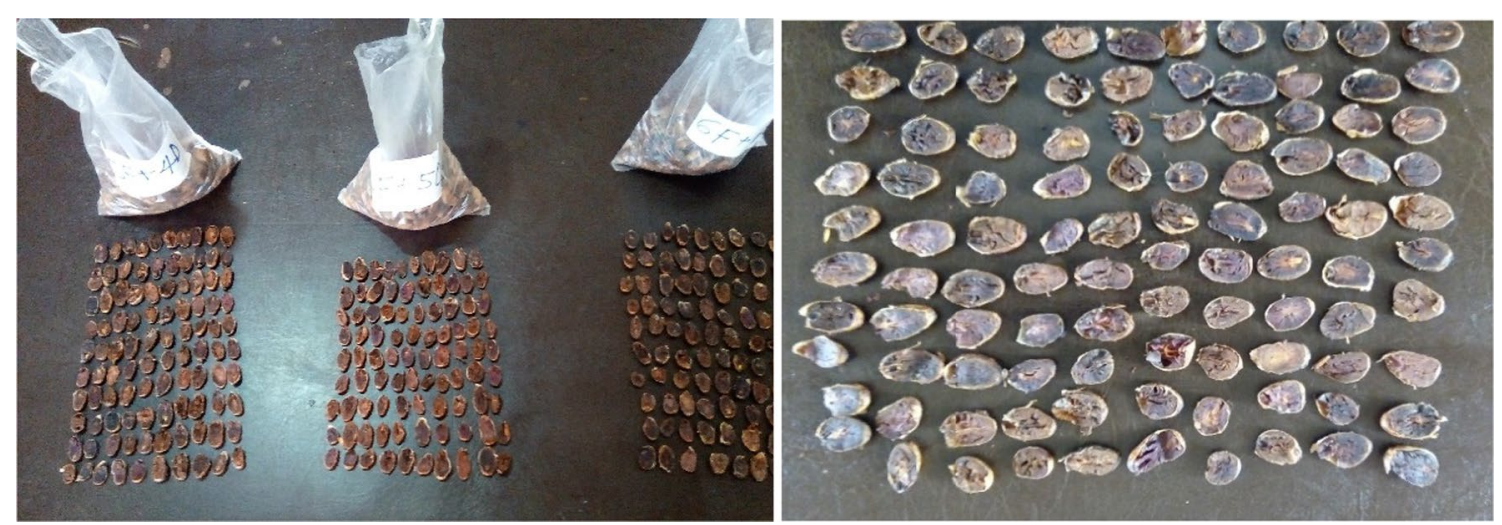

Fig. 3 Cross longitudinal section of cut cocoa beans for identifying defective beans after storage

beans. The storage was done in dry labelled Kenaf Jute sacks originally treated with vegetable oil according to industrial specifications by manufacturers (COCOBOD 2010) to maintain adequate ventilation around the beans. The beans were stored in a cocoa shed of $68 \%$ ambient humidity. The sacks were placed on dry gratings (wellcured wood) at $7 \mathrm{~cm}$ from the floor and $60 \mathrm{~cm}$ away from the walls of the shed and from each other.

\section{Data collection}

The following parameters were assessed in triplicates at the end of the storage period.

\section{Bean count and moisture content of beans after drying}

The bean count per $100 \mathrm{~g}$ (QCC 2010) and moisture content of fermented and dried beans were measured quantitatively at the end of each drying period. The moisture content of each fermented and dried sample was determined using a Moisture meter Aquaboy obtained from the Quality Control Division (QCD), Asempaneye district. The device has a portable electronic hygrometer, battery operated $(9 \mathrm{~V})$, accuracy of indication $\pm 0.1 \%$ at room temperature $20{ }^{\circ} \mathrm{C}$ and a range of $7-50 \%$, analogic reading. Figure 2 shows the bean count and moisture measurement process.

\section{Cut test attributes}

A hundred beans (divided into three replicates) from each dried sample were cut longitudinally across the broader surface as shown in Fig. 3, and the various defects were recorded.

The following qualitative data were collected from the cut test;

\section{Percentage mould (\% M)}

Cut beans that were mouldy depicted by greyish colouration be it internal or external were counted from 100 cut beans in triplicate and average estimated. This was expressed as a percentage using Eq. 1 (QCC 2010) to obtain percentage mould:

$$
\% \text { Mouldy beans }(\% \mathrm{M})=\frac{\text { Number of mouldy beans }}{\text { Total number of beans cut }} \times 100
$$




\section{Percentage slaty beans}

Slaty beans were counted from the triplicate cut beans for each treatment combination and the average expressed as a percentage using Eq. 2 (QCC 2010):

$$
\% \text { Slaty beans }(\% \mathrm{~S})=\frac{\text { Number of slaty beans }}{\text { Total number of beans cut }} \times 100
$$

\section{Percentage purple beans}

Purple beans obtained from 100 beans from each treatment combination were expressed as a percentage using Eq. 3 (QCC 2010):

$$
\% \text { Purple beans }(\% \mathrm{P})=\frac{\text { Number of purple beans }}{\text { Total number of beans cut }} \times 100
$$

\section{Percentage purity}

Purity, as a measure of the overall effect of the observed defects on the quality of cocoa beans, was expressed as a percentage by Eq. 4 (QCC 2010):

$$
\% \text { Purity }(\mathrm{P})=100 \%-[\% \mathrm{M}+\% \mathrm{~S}+\% \mathrm{P}]
$$

where $\% \mathrm{M}=$ percentage Mouldy beans found, $\% \mathrm{~S}=$ percentage Slaty beans found, $\% \mathrm{P}=$ percentage Purple beans found.

\section{Data analysis}

Numerical data collected from the fieldwork were subjected to statistical analyses using analysis of variance, with GenStat version 11.1. Here, significant differences were observed, the Least Significant Difference (LSD) criterion was used to separate the means at $5 \%$ level of probability.

\section{Results}

\section{Moisture content}

The moisture content of dry cocoa beans as influenced by different levels of fermentation and drying is presented in Table 1. Generally, moisture content declined with increasing duration of fermentation and drying. It was observed that moisture content declined from a maximum of $12.5 \%$ at 5 days to $11.9 \%$ at 6 days of fermentation and remained constant until day 7 before decreasing steadily again to a minimum of $8.4 \%$ when fermented for 8 days. Six and 7 days fermentation periods differed insignificantly $(p>0.05)$, while each of 5 and 8 days fermentation periods differed significantly $(p \leq 0.05)$ from the rest of the fermentation periods in terms of moisture content.

\begin{tabular}{|c|c|c|}
\hline Treatment & $\begin{array}{l}\text { Moisture } \\
\text { content (\%) }\end{array}$ & Bean count $/ 100 \mathrm{~g}$ \\
\hline \multicolumn{3}{|c|}{ Fermentation period (days) } \\
\hline 5 & $12.5 \mathrm{a}$ & $96 \mathrm{a}$ \\
\hline 6 & $11.9 b$ & $102 b$ \\
\hline 7 & $11.9 b$ & $103 b$ \\
\hline 8 & $8.4 c$ & $110 c$ \\
\hline LSD (0.05) & 0.45 & 3.136 \\
\hline \multicolumn{3}{|c|}{ Drying period (days) } \\
\hline 4 & $13.1 \mathrm{a}$ & $97 a$ \\
\hline 5 & $11.3 b$ & $104 b$ \\
\hline 6 & $8.9 \mathrm{c}$ & $108 c$ \\
\hline LSD (0.05) & 0.39 & 2.716 \\
\hline \multicolumn{3}{|l|}{ Interactions } \\
\hline $\mathrm{F} 5{ }^{*} \mathrm{D} 4$ & $14.1 \mathrm{a}$ & $89 a$ \\
\hline $\mathrm{F} 5 * \mathrm{D} 5$ & $12.0 \mathrm{~b}$ & $97 \mathrm{~b}$ \\
\hline $\mathrm{F} 5{ }^{*} \mathrm{D} 6$ & $11.4 b$ & 102 bcd \\
\hline F6*D4 & $13.4 \mathrm{a}$ c & $98 \mathrm{bc}$ \\
\hline F6*D5 & $13.0 \mathrm{C}$ & $103 \mathrm{~cd}$ \\
\hline F6*D6 & $9.4 \mathrm{~d}$ & $105 d$ \\
\hline $\mathrm{F} 7^{*} \mathrm{D} 4$ & $13.5 \mathrm{ac}$ & 99 bce \\
\hline $\mathrm{F} 7{ }^{*} \mathrm{D} 5$ & $12.0 \mathrm{~b}$ & 104 de \\
\hline $\mathrm{F} 7{ }^{*} \mathrm{D} 6$ & $9.3 \mathrm{~d}$ & $107 \mathrm{df}$ \\
\hline $\mathrm{F} 8 * \mathrm{D} 4$ & $11.3 b$ & $103 \mathrm{~cd}$ \\
\hline F8*D5 & $8.2 \mathrm{e}$ & $111 \mathrm{f}$ \\
\hline F8*D6 & $5.6 f$ & $117 \mathrm{~g}$ \\
\hline LSD (0.05) & 0.78 & 5.432 \\
\hline CV (\%) & 4.20 & 3.10 \\
\hline
\end{tabular}

Table 1 Moisture content and bean count of fermented and dried cocoa beans

Bolding was done to differentiate the treatment means from the rest of the content of the table

LSD, Least Significant Difference; CV, Coefficient of Variation

Within column means with different letters differ significantly $(p \leq 0.05)$

Drying fermented beans for 4 days in the rainy season resulted in moisture content of $13.1 \%$, while 5 and 6 days drying periods resulted in $11.3 \%$ and $8.9 \%$ moisture contents, respectively. All the applied drying periods differed significantly $(p \leq 0.05)$ in their effect on the moisture content of dry cocoa beans (Table 1 ).

Significant $(p \leq 0.05) \quad$ variations were observed amongst treatment interactions in terms of moisture content. Beans fermented and dried for 5 and 4 days, respectively, recorded the maximum moisture content of $14.1 \%$, preceded by beans fermented and dried for 7 and 4 days, respectively (13.5\%) and then by beans fermented and dried for 6 and 4 days, respectively (13.4\%). Fermenting and drying cocoa beans for 8 and 6 days, respectively, resulted in the significantly $(p \leq 0.05)$ lowest moisture content of $5.6 \%$, followed by 8 days of 
fermentation coupled with 5 days drying (8.2\%). No significant $(p>0.05)$ variations in moisture content were observed when 5, 6 and 7 days fermentation periods were coupled with 4 days drying period as well as when 6 and 7 days fermentation periods were coupled with 6 days drying period.

\section{Bean count $/ 100 \mathrm{~g}$}

Results on bean count for each $100 \mathrm{~g}$ of dry beans weighed are also shown in Table 1 . Bean count was found to show a reverse of the moisture characteristics, thus, number of beans/100 g increased with increasing fermentation and drying periods. Bean count was significantly $(p \leq 0.05)$ highest (110 beans/100 g) for beans fermented for 8 days and lowest ( 96 beans $/ 100 \mathrm{~g}$ ) when fermented for 5 days. No significant $(p>0.05)$ variation occurred between 6 and 7 days fermentation periods. Each of 5 and 8 days fermentation periods however

Table 2 Cut test results of fermented and dried cocoa beans

\begin{tabular}{|c|c|c|c|}
\hline Treatment & Mouldy beans (\%) & Purple beans (\%) & Slaty beans (\%) \\
\hline \multicolumn{4}{|c|}{ Fermentation period (days) } \\
\hline 5 & $18.00 \mathrm{a}$ & $6.33 a$ & $11.06 \mathrm{a}$ \\
\hline 6 & $14.40 \mathrm{a}$ & $2.22 \mathrm{~b}$ & $5.11 \mathrm{~b}$ \\
\hline 7 & $2.80 \mathrm{~b}$ & $2.67 b$ & $6.67 b$ \\
\hline 8 & $1.90 \mathrm{~b}$ & $1.22 b$ & $3.61 b$ \\
\hline LSD (0.05) & 6.20 & 1.615 & 3.151 \\
\hline \multicolumn{4}{|c|}{ Drying period (days) } \\
\hline 4 & $23.80 a$ & $3.08 \mathrm{a}$ & $9.08 \mathrm{a}$ \\
\hline 5 & $3.30 \mathrm{~b}$ & $3.42 \mathrm{a}$ & $6.79 a$ \\
\hline 6 & $0.80 \mathrm{~b}$ & $2.83 a$ & $3.96 c$ \\
\hline LSD (0.05) & 5.37 & 1.399 & 2.728 \\
\hline \multicolumn{4}{|l|}{ Interactions } \\
\hline $\mathrm{F} 5 * \mathrm{D} 4$ & $41.70 \mathrm{a}$ & $6.00 \mathrm{ac}$ & $12.67 \mathrm{a}$ \\
\hline $\mathrm{F} 5 * \mathrm{D} 5$ & $10.70 b$ & $7.00 \mathrm{a}$ & $11.33 \mathrm{a}$ \\
\hline $\mathrm{F} 5 * \mathrm{D} 6$ & $1.70 \mathrm{~b}$ & $6.00 \mathrm{ac}$ & $9.17 \mathrm{abd}$ \\
\hline $\mathrm{F} 6^{*} \mathrm{D} 4$ & $40.00 \mathrm{a}$ & $1.33 \mathrm{bd}$ & $8.67 \mathrm{abd}$ \\
\hline $\mathrm{F} 6{ }^{*} \mathrm{D} 5$ & $2.50 \mathrm{~b}$ & $2.50 \mathrm{bd}$ & 4.17 bcde \\
\hline $\mathrm{F} 6 * \mathrm{D} 6$ & $0.80 \mathrm{~b}$ & $2.83 \mathrm{bd}$ & 2.50 cde \\
\hline $\mathrm{F} 7^{*} \mathrm{D} 4$ & $7.50 \mathrm{~b}$ & $3.33 \mathrm{bc}$ & $10.00 \mathrm{ad}$ \\
\hline $\mathrm{F} 7{ }^{*} \mathrm{D} 5$ & $0.00 \mathrm{~b}$ & $2.50 \mathrm{bd}$ & $7.50 \mathrm{abcd}$ \\
\hline $\mathrm{F} 7{ }^{*} \mathrm{D} 6$ & $0.80 \mathrm{~b}$ & $2.17 \mathrm{bd}$ & 2.50 cde \\
\hline $\mathrm{F} 8 * \mathrm{D} 4$ & $5.80 \mathrm{~b}$ & $1.67 \mathrm{bd}$ & $5.00 \mathrm{de}$ \\
\hline $\mathrm{F} 8 * \mathrm{D} 5$ & $0.00 \mathrm{~b}$ & $1.67 \mathrm{bd}$ & 4.17 bcde \\
\hline $\mathrm{F} 8^{*} \mathrm{D} 6$ & $0.00 \mathrm{~b}$ & $0.33 d$ & $1.67 \mathrm{e}$ \\
\hline LSD (0.05) & 10.73 & 2.798 & 5.457 \\
\hline CV (\%) & 68.50 & 53.40 & 49.00 \\
\hline
\end{tabular}

Bolding was done to differentiate the treatment means from the rest of the content of the table

LSD, Least Significant Difference; CV, Coefficient of Variation

Within column means with different letters differ significantly $(p \leq 0.05)$ varied significantly $(p \leq 0.05)$ from the rest of the fermentation periods.

Bean count was as well significantly $(p \leq 0.05)$ highest ( 108 beans $/ 100 \mathrm{~g}$ ) when dried for 6 days and lowest (97 beans/100 g) when dried for 4 days. All the applied drying periods varied significantly $(p \leq 0.05)$ in terms of bean count/100 g.

There were significant $(p \leq 0.05)$ variations amongst the combined factor treatments in terms of bean count $/ 100$ g. Bean count was highest (117 beans/100 g) for beans fermented and dried for 8 and 6 days, respectively, followed by beans fermented and dried for 8 and 5 days ( 111 beans $/ 100 \mathrm{~g}$ ), respectively, and the lowest (89 beans $/ 100 \mathrm{~g}$ ) when fermented and dried for 5 and 4 days, respectively.

\section{Cut test attributes}

Cut test results of fermented and dried cocoa beans are presented in Table 2.

\section{A. Percentage mouldy beans}

It was observed that the percentage of mouldy beans decreased steadily from 5 to 6 days fermentation period and rapidly with further increase in fermentation period. No significant ( $\mathrm{p}^{\prime} 0.05$ ) variations occurred between 5 and 6 days fermentation periods, as well as between 7 and 8 days periods of fermentation. Both 5 and 6 days fermentation periods however varied significantly $(\mathrm{p} \leq 0.05)$ from 7 and 8 days fermentation periods. Cocoa fermented for 5 days recorded the highest percentage mould (18.0\%), while 8 days fermentation period recorded the lowest (1.90\%).

Percentage mouldy beans decreased rapidly with increasing drying duration. Five and 6 days drying periods were at par $(p>0.05)$ in terms of percentage mouldy beans but both varied significantly $(\mathrm{p} \leq 0.05)$ from 4 days drying period. Cocoa dried for 4 days were highest in mould content (23.3\%) preceded by those dried for 5 days (3.30\%) with 6 days dried beans recording the significantly lowest $(0.80 \%)$.

There were significant $(\mathrm{p} \leq 0.05)$ combined treatment factor variations in terms of $\%$ mouldy beans. Interactively, beans fermented and dried for 5 and 4 days, respectively, were highest $(41.70 \%)$ in mould content followed by beans fermented and dried for 6 and 4 days (40.00\%), respectively, with 6 and 7 days fermentation coupled with 6 days drying recording the lowest $(0.80 \%)$. Seven and 8 days fermentation coupled with 5 days drying as well as 8 days fermentation coupled with 6 days drying however recorded no mouldy bean $(0.00 \%)$.

\section{B. Percentage purple beans}


Results on percentage purple beans as influenced by different fermentation and drying durations are also presented in Table 2. Percentage purple in cocoa fermented for 5 days was significantly $(\mathrm{p} \leq 0.05)$ higher $(6.33 \%)$ than that recorded for the rest of the fermentation periods with the 8 days fermented cocoa recording the lowest purple percentage of $1.22 \%$. Purple content in beans fermented for 6,7 and 8 days however showed no significant $(\mathrm{p}>0.05)$ variations.

No significant $(\mathrm{p}>0.05)$ variations existed amongst the applied drying durations in terms of percentage purple. Beans dried for 5 days however recorded the highest purple content of 3.42\% with those dried for 6 days recording the lowest (2.83\%).

Significant $(\mathrm{p} \leq 0.05)$ variations were observed upon interacting treatment factors. Percentage purple was highest $(7.00 \%)$ for beans fermented and dried for 5 days, followed by 5 days fermentation coupled with either of 4 and 6 days drying which resulted in the same purple content of $6.00 \%$. Beans fermented and dried for 8 and 6 days, respectively, recorded the significantly $(\mathrm{p} \leq 0.05)$ lowest purple percent $(0.33 \%)$.

\section{Percentage slaty beans}

The slaty bean content observed from the cut test showed no significant $(p>0.05)$ variation amongst 6,7 and 8 days fermentation periods, while 5 days fermented beans recorded the significantly $(p \leq 0.05)$ highest slaty content of $11.06 \%$ with 8 days fermented beans recording the lowest (3.61\%) (Table 2).

It was also revealed that slaty content decreased with increasing drying duration. Cocoa dried for 6 days recorded the significantly $(p \leq 0.05)$ lowest slaty content of $3.96 \%$ as compared to the rest of the drying periods which recorded statistically similar slaty content, although highest for 4 days dried cocoa (9.08\%).

There were significant $(p \leq 0.05)$ variations amongst treatment interactions in terms of slaty bean content. Interacting short fermentation periods with short drying durations generally revealed high slaty content and vice versa. Five days fermentation coupled with 4 days drying resulted in the highest slaty content of $12.67 \%$ preceded by beans fermented and dried for 5 days (11.33\%) with 8 days fermentation coupled with 6 days drying resulting in the lowest (1.67\%). Coupling the different drying durations with the same fermentation period, however, showed no significant $(p>0.05)$ variation in slaty content.

\section{Percentage purity}

Figure 4 shows levels of percentage purity as a cumulative measure of the effects of the various defects on the quality of cocoa beans from the cut test under the various treatments. Tabular results also are presented in Table 3.

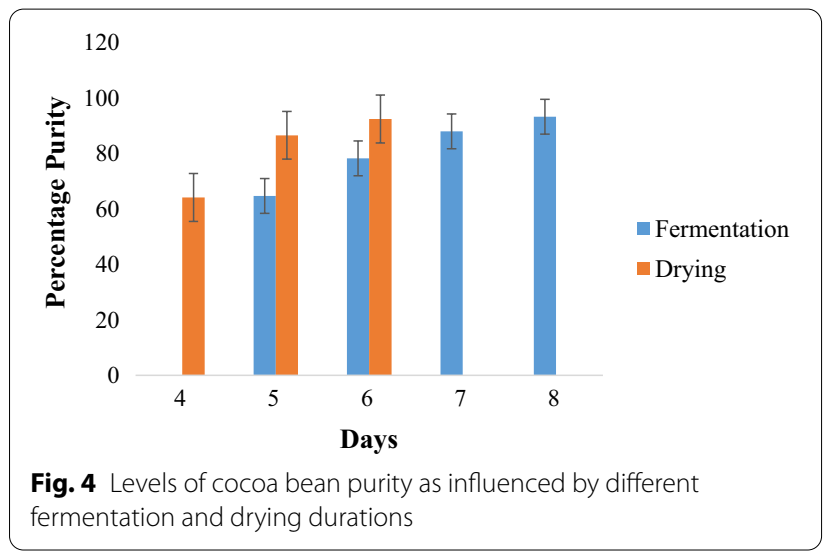

Unlike moisture content, percentage purity increased with increasing fermentation and drying duration as shown in Fig. 4. The highest purity (93.22\%) was recorded for

Table 3 Percentage purity of fermented and dried cocoa beans

\begin{tabular}{ll}
\hline Treatment & Purity (\%) \\
\hline Fermentation period (days) & \\
5 & $64.61 \mathrm{a}$ \\
6 & $78.22 \mathrm{~b}$ \\
7 & $87.89 \mathrm{c}$ \\
8 & $93.22 \mathrm{c}$ \\
LSD (0.05) & $\mathbf{7 . 0 1 5}$ \\
Drying period (days) & \\
4 & $64.08 \mathrm{a}$ \\
5 & $86.50 \mathrm{~b}$ \\
6 & $92.38 \mathrm{~b}$ \\
LSD (0.05) & $\mathbf{6 . 0 7 5}$ \\
Interactions & \\
F5*D4 & $39.67 \mathrm{a}$ \\
F5*D5 & $71.00 \mathrm{~b}$ \\
F5*D6 & $83.17 \mathrm{c}$ \\
F6*D4 & $50.00 \mathrm{a}$ \\
F6*D5 & $90.83 \mathrm{~cd}$ \\
F6*D6 & $93.83 \mathrm{~cd}$ \\
F7*D4 & $79.17 \mathrm{~b}$ \\
F7*D5 & $90.00 \mathrm{~cd}$ \\
F7*D6 & $94.50 \mathrm{~cd}$ \\
F8*D4 & $87.50 \mathrm{~cd}$ \\
F8*D5 & $94.17 \mathrm{~cd}$ \\
F8*D6 & $98.00 \mathrm{~d}$ \\
LSD (0.05) & $\mathbf{1 2 . 1 4 9}$ \\
CV (\%) & $\mathbf{8 . 9}$ \\
\hline B & \\
\hline & \\
&
\end{tabular}

Bolding was done to differentiate the treatment means from the rest of the content of the table

LSD, Least Significant Difference; CV, Coefficient of Variation

Within column means with different letters differ significantly $(p \leq 0.05)$ 
8 days fermented beans and the lowest (64.61\%) for 5 days fermented beans. Percentage purity for 7 and 8 days fermented beans varied insignificantly $(p>0.05)$, while each of 5 and 6 days fermented beans varied significantly $(p \leq 0.05)$ from the rest of the fermentation periods in terms of purity.

Drying fermented cocoa for 6 days resulted in the highest purity (92.38\%), while 4 days drying period resulted in the lowest purity of $64.08 \%$. Percentage purity for 4 days dried cocoa varied significantly $(p \leq 0.05)$ from 5 and 6 days dried beans which were at par $(p>0.05)$ statistically.

Significant $(p \leq 0.05)$ treatment interactions were observed in terms of percentage purity. Cocoa fermented and dried for 8 and 6 days, respectively, resulted in the highest purity of $98.00 \%$ preceded by cocoa fermented and dried for 7 and 6 days, respectively (94.50\%) with beans fermented and dried for 5 and 4 days recording the lowest (39.67\%).

\section{Discussion \\ Effects of fermentation and drying durations on bean moisture content}

Though the applied fermentation and drying periods single handedly resulted in moisture content higher than the recommended, coupling 8 days fermentation with 6 days drying period resulted in a moisture content of $5.6 \%$ which falls below the acceptable standard (7.5\%) recommended by buyers. At this level of moisture content, incidence of mould and brittle bean is significantly minimized if not eliminated. Otomfo (2014) also reported that the percentage rate of change in moisture content in different duration of fermentation of cocoa beans prior to drying varied significantly.

\section{Effects of fermentation and drying durations on bean count/100 g}

The entire results indicated that bean count values were more than 100 beans per $100 \mathrm{~g}$ when fermented and dried for more than 5 and 4 days, respectively. However, beans were favourably heavier than $1 \mathrm{~g}$ on the average as required for the export market (ICCO 2007) when fermented and dried for 5 and 4 days, respectively. Coupling a short fermentation period with short drying period resulted in heavier bean weight and less when longer fermentation periods were coupled with longer drying periods. Bean weight was however optimal when 5 and 6 days fermentation periods were coupled with optimum (5) and short (4) drying periods, respectively. The higher number of beans per $100 \mathrm{~g}$ of cocoa observed in beans fermented and dried for longer periods at favourable moisture content (7.5\%) may be attributed to high loss of nutrient components as a result of senescence, while the lesser number of beans with shorter fermentation and drying periods may be due to high moisture content.

\section{Effects of fermentation and drying durations on cut test attributes and Bean Purity}

It can be inferred from the results that 7 and 8 days fermentation as well as 6 days drying periods produced mouldy beans which are within the acceptable grade 1 limit of 3\% mould for industry and commerce. Coupling any of the fermentation periods with moderate or longer drying duration (5 and 6 days, respectively) also gave results which were within the acceptable grade 1 limit, while 4 days drying duration resulted in high mould content above the acceptable irrespective of fermentation duration. The high mould content of beans with short drying durations (4 days in the case of this study) may be attributed to the high degree of respiration, chemical and enzymatic activity of the beans and microbial content increased due to increased moisture content (LagunesGálvez et al. 2007). According to the study by Otomfo (2014), moisture activities around cocoa beans under fermentation may aid this microbial (mould) activity.

Though the entire study revealed that each fermentation and drying duration recording acceptable levels of purple, which was less than the maximum $20 \%$ for grade 1 cocoa as recommended by Wood and Lass (1985), 5 days fermentation period resulted in a more or less higher purple content irrespective of drying duration, while longer fermentation period coupled with any drying duration resulted in very encouraging and minimal values of purple.

Though all fermentation and drying durations resulted in slaty content higher than the acceptable grade 1 limit (3\%), coupling 6, 7 or 8 days fermentation period with 6 days drying resulted in slaty content which fell below the grade 1 limit, while coupling 5, 6 and 7 days fermentation periods with 4 days drying duration all resulted in slaty content falling even above the acceptable grade 2 limit (8\%). This could be attributed to the higher amounts of anthocyanin content in poorly dried cocoa beans. It has been reported in work done on effects of pulp preconditioning and over fermentation on slaty and purple presence in cocoa that adequate duration of fermentation generates fermentative quality and desired chocolate colour (Guehi et al. 2008).

Percentage purity as the overall assessment of the impact of all the defects on the quality of the cocoa under consideration indicated an overall superior performance of increasing fermentation and drying durations. Longer fermentation compared favourably with longer drying period. The purity levels for the various fermentation and drying durations followed suit the direct opposite of the decreasing levels of the defects with increasing durations of fermentation and drying. 


\section{Conclusions}

The study showed that the longer the fermentation and drying durations, the more efficient the fermentation and the drying processes as indicated by the percentage moisture, mould, purple and slaty found compared to the amounts found when both fermentation and drying durations were shortened. Longer fermentation period coupled favourably with longer drying duration. Shorter fermentation and drying durations depicted high moisture content which resulted in a high incidence of defective beans while longer fermentation and drying durations revealed bean underweight. The overall effect of the treatments on the quality attributes from the cut test revealed that 8 days fermentation period with the traditional leaf heap method, coupled with 6 days sundrying resulted in superior bean quality.

\section{Abbreviations}

CRD: Completely randomized design; CRIG: Cocoa Research Institute of Ghana; FAO: Food and Agriculture Organization; GDP: Gross domestic product; ICCO: International Cocoa Organization; LSD: Least significant difference; QCC: Quality control company.

\section{Acknowledgements}

The Authors thank the Quality Control Company Limited (QCC), Asempaneye District for supporting them with devices including electronic scale and moisture meter aquaboy for the data collection and providing guidance for the identification of cut test attributes.

\section{Authors' contributions}

ED. conceived the original idea and assisted in data collection. EA. contributed the experimental design, carried out the experiment, performed analytical computations and wrote the first draft of the manuscript. Both authors read and approved the final manuscript for submission.

\section{Funding}

No funding was obtained for this study.

\section{Declarations}

Ethics approval and consent to participate

The studies involved in this article did not included animals or human participants as objects of research.

\section{Consent for publication}

Not applicable.

\section{Availability of data and material}

The data used to support the findings of this study are available from the corresponding author upon request.

\section{Competing interests}

The authors declare that they have no conflict of interest.

\section{Author details}

${ }^{1}$ Department of Crop and Soil Science, College of Agriculture Education, University of Education, Winneba, Ashanti-Mampong, Ghana. ${ }^{2}$ Department of Agronomy, University College of Agriculture and Environmental Studies, Bunso, Ghana.

Received: 26 March 2021 Accepted: 5 October 2021

Published online: 19 October 2021

\section{References}

Adeniyi DO, Oyedokun AV, Adejobi KB, Adenuga OO (2011) Mycoflora associated with fermentation of cocoa beans in Nigeria. J Appl Biosci 39:2647-2651

Adeyeye El, Akinyeye RO, Ogunlade I, Olaofe O, Boluwade JO (2010) Effect of farm and industrial processing on the amino acid profile of cocoa beans. Food Chem 118:357-363

Afoakwa EO (2010) Chocolate science and technology, vol 687. Wiley, Oxford Afoakwa EO, Kongor JE, Budu AS, Mensah-Brown H, Takrama JF (2015) Changes in some biochemical qualities during drying of pulp pre-conditioned and fermented cocoa (Theobroma cacao) beans. Afr J Food Agric Nutr Dev 15(1):9651-9670

Anyidoho EK (2015) The effects of moisture and fermentation periods on the physical and biochemical properties of 'amelonado'and 'hybrid'varieties of cocoa beans. Doctoral dissertation, University of Cape Coast

COCOBOD (2010) Cocobod news. A publication of Ghana Cocoa Board, vol $9(6)$

Coe SD, Coe MD (2013) The true history of chocolate. Thames \& Hudson, London

Danker WJ (2002) Profit for the lord: economic activities in moravian missions and the basel mission trading company. Wipf and Stock Publishers

Dharmaputra OS (1999) The occurrence of insects and moulds in stored cocoa beans at South Sulawesi. BIOTROPIA Southeast Asian J Trop Biol, 12

Food and Agriculture Organization of the United Nations (2003) Medium-term prospects for agricultural commodities-projections to the year 2010

Ghana Statistical Service (2014) Population and Housing Census, 2010. Juaboso District

Guehi TS, Yao ND, Manizan NP, Nevry KR, Koffi LB, Konan YM (2008) Comparison of the degree of fermentation and fungal profiles of raw cocoa beans sourced from three Ivorian main producing regions. Afr J Food Sci 2:112-118

Guehi TS, Zahouli IB, Ban-Koffi L, Fae MA, Nemlin JG (2010) Performance of different drying methods and their effects on the chemical quality attributes of raw cocoa material. Int J Food Sci Technol 45(8):1564-1571

ICCO (International Cocoa Organization) (2007) Assessment of the Movement of Global Supply and Demand. Market Committee, 6th meeting. Exists as a download file at http://www.icco.org/economics/consultive.aspx

International Cocoa Organization (ICCO) (2013) ICO quarterly bulletin of cocoa statistics, XXXIX (2). London, UK

International Trade Centre UNCTAD/WTO (2001) Cocoa: a guide to trade practices. United Nations Publications

Jonfia-Essien WA (2001) The effect of storage on the quality of cocoa beans. Internal Report

Kouadio AKA, Sadat AW, Assidjo NE, Kouame LP (2015) Etude de la qualite physico-chimique et mycologique du cacao (Theobroma cacao) produit dans les zones de yamoussoukro et soubre (Côte d'Ivoire)[Study of physicochemical and mycologic quality of Theobroma Cocoa product in Yamoussoukro and Soubré (Côte d'Ivoire)]

Kyi TM, Daud WRW, Mohammad AB, Wahid Samsudin M, Kadhum AAH, Talib MZM (2005) The kinetics of polyphenol degradation during the drying of Malaysian cocoa beans. Int J Food Sci Technol 40(3):323-331

Lagunes-Gálvez S, Loiseau G, Paredes JL, Barel M, Guiraud JP (2007) Study on the microflora and biochemistry of cocoa fermentation in the Dominican Republic. Int J Food Microbiol 114:124-130

Lasisi D (2014) A comparative study of effects of drying methods on quality of cocoa beans. IJERT Int J Eng Res Technol 3(1):991-996

Lefeber T, Janssens M, Camu N, De Vuyst L (2010) Kinetic analysis of strains of lactic acid bacteria and acetic acid bacteria in cocoa pulp simulation media toward development of a starter culture for cocoa bean fermentation. Appl Environ Microbiol 76(23):7708-7716

Nair KP (2010) The agronomy and economy of important tree crops of the developing world. Elsevier, Amsterdam

Navarro S, Navarro H, Finkelman S, Jonfia-Essien WA (2010) A novel approach to the protection of cocoa beans by preventing free fatty acid formation under hermetic storage. In Fumigation, modified atmospheres and hermetic storage, proceedings of the 10th international working conference on stored product protection, vol 27, pp 390-395

Ntiamoah A, Afrane G (2008) Environmental impacts of cocoa production and processing in Ghana: life cycle assessment approach. J Clean Prod 16(16):1735-1740 
Otomfo AT (2014) Effect of stages of ripening and tray fermentation method on the quality of cocoa (Theobroma cacao) beans. Doctoral dissertation Presilla ME (2009) The new taste of chocolate: a cultural and natural history of cacao with recipes. Random House Digital, Inc

Quality Control Company (QCC) (2010) Annual newsletter 9(2):7-9

Rossini K, Noreña CPZ, Brandelli A (2011) Changes in the color of white chocolate during storage: potential roles of lipid oxidation and non-enzymatic browning reactions. J Food Sci Technol 48:305-311

Schwan RF, Wheals AE (2004) The microbiology of cocoa fermentation and its role in chocolate quality. Crit Rev Food Sci Nutr 44(4):205-221

Thompson SS, Miller KB, Lopez AS (2001) Cocoa and coffee. In: Doyle MP, Beuchat LR, Montville TJ (eds), Food microbiology: fundamentals and frontiers
Wood GAR, Lass RA (1985) Cocoa, 4th ed. Longman Group Limited, London, pp 444-587

Yao KM, Kambiré O, Kouassi KC, Koffi-névry R, Guéhi TS (2017) Risk prevention of fungal contamination of raw cocoa beans in Côte d 'Ivoire: case of polyhexamethylene guanidine hydrochloride (PHMGH). Food Public Health 7(2):40-50. https://doi.org/10.5923/j.fph.20170702.03

\section{Publisher's Note}

Springer Nature remains neutral with regard to jurisdictional claims in published maps and institutional affiliations.

\section{Submit your manuscript to a SpringerOpen ${ }^{\circ}$ journal and benefit from:}

- Convenient online submission

- Rigorous peer review

- Open access: articles freely available online

- High visibility within the field

Retaining the copyright to your article

Submit your next manuscript at $\boldsymbol{\nabla}$ springeropen.com 